\section{Clinical, hematological, and molecular characterization of sickle cell anemia pediatric patients from two different cities in Brazil}

\author{
Caracterização clínica, hematológica e molecular \\ de crianças portadoras da anemia falciforme \\ em duas diferentes cidades do Brasil
}

\author{
Isa Menezes Lyra 1,2 \\ Marilda Souza Gonçalves 3,4 \\ Joseffina A. Pellegrinei Braga 5 \\ Maria de Fátima Gesteira 2 \\ Maria Helena Carvalho 6 \\ Sara Terezinha Olalla Saad 6 \\ Maria Stella Figueiredo 5 \\ Fernando Ferreira Costa 6
}

\footnotetext{
1 Fundação Hematologia e Hemoterapia da Bahia, Salvador, Brasil.

2 Universidade Federal da Bahia, Salvador, Brasil. 3 Centro de Pesquisa Gonçalo Moniz, Fundação Oswaldo Cruz, Salvador, Brasil. 4 Faculdade de Farmácia, Universidade Federal da Bahia, Salvador, Brasil. 5 Universidade Federal de São Paulo, São Paulo, Brasil. 6 Centro de Hematologia e Hemoterapia, Universidade Estadual de Campinas, Campinas, Brasil.

Correspondence I. M. Lyra Fundação de Hematologia e Hemoterapia da Bahia. Av. Vasco da Gama s/n. Salvador, $B A$ 40240-090, Brasil. isa.lyra@terra.com.br
}

\begin{abstract}
This study focused on clinical, hematological, and molecular aspects of sickle cell anemia pediatric patients from two different cites in Brazil. Seventy-one patients from São Paulo and Salvador, aged 3 to 18 years, were evaluated. Hematological analyses, $\beta^{S}$ globin gene haplotypes, and $\alpha_{2}{ }^{3.7 k b-t h a l a s s e m i a ~ w e r e ~ p e r f o r m e d . ~ N u m-~}$ bers of hospitalizations due to vaso-occlusive crises, infections, stroke, and cholelithiasis were investigated. São Paulo had more hospitalizations from vaso-occlusion, cholelithiasis, and stroke than Salvador. The Ben/CAR genotype predominated in both cities. $\alpha_{2}{ }^{3.7 k b-t h a l a s s e m i a ~}$ had a frequency of $28.2 \%$ in Salvador, mostly with Ben/CAR genotype (45.0\%), while São Paulo had $22.5 \%$ with similar frequencies of the Ben/ CAR and CAR/CAR genotypes. Sickle cell anemia patients from São Paulo also had more episodes of stroke, which was observed among CAR/CAR, atypical, and BEN/CAR haplotypes. In Salvador stroke was only observed in the Ben/CAR genotype. Cholelithiasis had similar frequencies in the two cities. These data suggest a milder phenotype among patients in Salvador, possibly due to genetic, environmental, and socioeconomic factors. Further studies are needed to elucidate modulating factors and phenotype association.
\end{abstract}

Sickle Cell Anemia; Alpha-Thalassemia; Haplotypes; Pediatrics
Sickle cell anemia has a heterogeneous clinical course with a variability of symptoms among individuals and in the same or different geographic locations 1 . The disease has complex clinical features that can be modified by age, gender, genetic, hematological, and environmental factors 2 .

Millions of people are affected by sickle cell disease throughout the world 3 . In Brazil, estimates indicate that $5.0-6.0 \%$ of the population carry the hemoglobin S gene 4 , and 700 to 1,000 new cases of sickle cell disease occur per year 5. The country has a varied environmental and socioeconomic distribution. The Southeast region includes the city of São Paulo in São Paulo State, and the Northeast region the city of Salvador in Bahia State (the two cities are their respective State capitals) 6 . The ethnic origin of the Brazilian population is heterogeneous and unevenly distributed. Some 2.5-40 million slaves were brought to Brazil from Africa through the slave trade and were distributed in nearly all regions of the country 7,8. São Paulo received slaves mainly from Mozambique, while in Bahia nearly all the slaves came from Benin 9. São Paulo city has 10,677,019 million inhabitants and an infant mortality rate of 15.3 per 1,000 live births as of 2001. Salvador has 2,556,429 million inhabitants and an infant mortality rate of 34.11 per 1,000 live births as of 200210 . These data demonstrate the diversity of the Brazilian population. Considering these factors and the high 
variant hemoglobin frequency in our population, we decided to study hematological, clinical, and molecular aspects of sickle cell pediatric patients from these two Brazilian cities.

Seventy-one sickle cell patients 18 years of age and under were studied, 31 from São Paulo and 40 from Salvador. Age varied from 3 to 18 years, with a mean of $9.5 \pm 4.4$ years in São Paulo (15 males and 16 females) and $9.4 \pm 3.9$ in Salvador (15 males and 25 females). For statistical analyses of the prevalence of $\beta^{S}$ globin gene haplotypes and $\alpha_{2} 3.7 \mathrm{~kb}$-thalassemia, only unrelated patients were computed, and clinical manifestations were observed in all children (number of hospitalizations due to vaso-occlusive crises, infections, stroke, and cholelithiasis). Hematological tests were obtained by an automated cell counter (Coulter T 890), hemoglobin electrophoresis was performed on cellulose acetate strips at $\mathrm{pH} 8.4$, hemoglobin $\mathrm{A}_{2}$ quantified after elution from cellulose strips, and fetal hemoglobin assessed by the alkali denaturation procedure 11,12 . $\beta$ S-globin gene haplotypes were investigated by polymerase chain reaction (PCR) and the haplotype polymorphic sites identified by restriction fragment length polymorphism analysis (RFLP) as previously described 13. $\alpha_{2} 3.7 \mathrm{~kb}$-thalassemia was determined by the Southern blot technique and digestion by specific enzymes as described 14,15. Student's t-test, Spearman rank correlation, and chi-square or Fisher's test were used in the statistical analysis.

Table 1 shows distribution of $126 \beta^{\text {S }}$ chromosomes analyzed in the two cities. In this study Ben chromosome predominated in Salvador, whereas CAR had a slightly higher frequency in São Paulo. Ben/CAR (54.0\% Salvador $\mathrm{x} 40.0 \%$ São Paulo) genotype predominated in both cities. The CAR/CAR (32.0\% São Paulo $\mathrm{x}$ $20.0 \%$ Salvador) and atypical genotypes (Atp) were more frequent in São Paulo (18.0\% São Paulo x 6.0\% Salvador). $\alpha_{2} 3.7 \mathrm{~kb}$-thalassemia was detected in 11/39 (28.2\%) in Salvador and 6/31 (22.5\%) in São Paulo.

Patients from São Paulo had more vaso-occlusive hospitalizations and stroke episodes ( $\mathrm{p}$ $<0.05$ ). When clinical manifestations related to haplotypes were analyzed, patients with genotype CAR/Ben and CAR/CAR showed more admissions due to vaso-occlusion in both cities, infections were associated with Ben/CAR and Ben/Ben in Salvador and Ben/CAR and CAR/ CAR in São Paulo. Stroke was more frequent in the Ben/CAR genotype in Salvador and CAR/ CAR in São Paulo. Cholelithiasis was associated with the atypical group in Salvador and the CAR/CAR genotype in São Paulo (data shown in Table 2).

Frequency of $\alpha_{2} 3.7 \mathrm{~kb}$-thalassemia was similar in the two groups, with $11 / 39(28.2 \% ; 11 / 39)$ in Salvador and 6/31(22.5\%) in São Paulo, mostly represented by the Ben/CAR genotype in Salvador, and in São Paulo with similar frequencies for Ben/CAR and CAR/CAR genotypes. The clinical events did not reach statistical significance.

Genotype distribution in the two cities shows a different pattern, with a higher frequency of the Ben chromosome in Salvador as compared to CAR in São Paulo. This is in agreement with the slave traffic theory by Philip Curtain ${ }^{9}$ suggesting that Bahia received individuals from West Africa, where the Ben haplotype predominates.

This is the first study comparing pediatric Brazilian sickle cell patients from two different States with the aim of identifying clinical parameters of evolution related to the genotype and also considering phenotypic aspects. Further aspects could be elucidated using a different approach that included adult patients in order to provide more information on different molecular and clinical characteristics of sickle cell anemia.

\begin{tabular}{|c|c|c|c|c|}
\hline \multirow[t]{2}{*}{ Chromosome } & \multicolumn{2}{|c|}{ Salvador } & \multicolumn{2}{|c|}{ São Paulo } \\
\hline & $\mathrm{n}$ & $\%$ & $\mathrm{n}$ & $\%$ \\
\hline Ben & 34 & 48.0 & 19 & 34.0 \\
\hline CAR & 34 & 48.0 & 31 & 55.0 \\
\hline Atypical & 2 & 3.0 & 6 & 8.5 \\
\hline Total & 70 & 100.0 & 56 & 100.0 \\
\hline
\end{tabular}


Frequency of clinical manifestations in different $\beta$ S globin genotypes in Brazilian sickle cell anemia patients from Salvador and São Paulo, Brazil.

\begin{tabular}{|c|c|c|c|c|c|c|c|c|}
\hline \multirow[t]{2}{*}{ Haplotype } & \multicolumn{4}{|c|}{ Salvador } & \multicolumn{4}{|c|}{ São Paulo } \\
\hline & $\begin{array}{c}\text { Hospital } \\
\text { admissions } \\
\text { vaso-occlusion }\end{array}$ & $\begin{array}{l}\text { Hospital } \\
\text { admissions } \\
\text { infection }\end{array}$ & Stroke & Lithiasis & $\begin{array}{c}\text { Hospital } \\
\text { admissions } \\
\text { vaso-occlusion }\end{array}$ & $\begin{array}{l}\text { Hospital } \\
\text { admissions } \\
\text { infection }\end{array}$ & Stroke & Lithiasis \\
\hline Ben/CAR & 41 & 27 & 2 & 3 & 82 & 18 & 1 & 3 \\
\hline CAR/CAR & 14 & 4 & 0 & 1 & 28 & 14 & 2 & 3 \\
\hline Ben/Ben & 8 & 5 & 0 & 1 & 5 & 1 & 0 & 0 \\
\hline Atypical & 11 & 4 & 0 & 0 & 9 & 5 & 2 & 1 \\
\hline Total & 74 & 40 & 2 & 5 & 124 & 38 & 5 & 7 \\
\hline
\end{tabular}

\section{Resumo}

O objetivo desse estudo foi avaliar aspectos clínicos, hematológicos e moleculares de pacientes pediátricos portadores de anemia falciforme em duas cidades brasileiras: Salvador e São Paulo. Foram estudados 71 pacientes com idades variando entre 3 a 18 anos, analisando-se os seguintes aspectos: perfis hematológicos, haplótipos dos genes da globina $\beta$, presença de talassemia $\alpha-23.7 \mathrm{~kb}$, número de internações por vasooclusão, infecção, presença de acidente vascular cerebral e litíase biliar. O genótipo Ben/CAR predominou nas duas cidades. Talassemia $\alpha-2^{3.7 k b}$ teve freqüência de 28,2\% em Salvador e 22,5\% em São Paulo. Os pacientes de São Paulo apresentaram um número maior de internações por vaso-oclusão nos diferentes genótipos. Esses dados sugeriram um fenótipo com menor gravidade clinica nos pacientes de Salvador, possivelmente relacionados a fatores genéticos, ambientais $e$ sócio-econômicos. Estudos adicionais necessitam ser realizados com intuito de elucidar os efeitos moduladores na expressão gênica da doença.

Anemia Falciforme; Talassemia Alfa; Haplotipos; Pediatria

\section{Contributors}

I. M. Lyra participated in the blood sample collection, hemoglobin analysis, DNA extraction, molecular analyses, clinical data collection, data bank coordination, and analyses from the two cities, data interpretation and manuscript drafting and revision. M. S. Gonçalves participated in molecular analyses, data interpretation, and manuscript drafting and revision. J. P. Braga participated in the sample collection, clinical data compilation for São Paulo patients, and manuscript revision. M. F. Gesteira participated in the sample collection, clinical data compilation from Salvador patients, and manuscript revision. M. H. Carvalho participated in DNA extraction and molecular analyses. S. T. O. Saad participated in laboratory test supervision, data interpretation, and manuscript revision. M. S. Figueiredo participated in the sample collection, clinical data compilation from São Paulo patients, and manuscript revision. F. F. Costa participated in laboratory test supervision, data interpretation, and manuscript drafting and revision. 


\section{References}

1. Powars DR, Chanl L, Schoreder WA. Beta-S-genecluster haplotypes in sickle cell anemia: clinical implications. Am J Pediatr Hematol Oncol 1990; 12:367-74.

2. Dover GJ, Platt OS. Sickle cell disease. In: Nathan DG, Orkin SH, editors. Nathan and Oiski's hematology of infancy and childhood. Philadelphia: WB Saunders Co.; 1998. p. 762-810.

3. Bunn HF, Forget BG, editors. Hemoglobin: molecular, genetic and clinical aspects. Philadelphia: W.B. Saunders Company; 1986.

4. Salzano FM. Incidence, effects and management of sickle cell disease in Brazil. Am J Pediatr hematol Oncol 1985; 7:240-4.

5. Zago MA. Considerações gerais. In: Agência Nacional de Vigilância Sanitária, organizador. Manual de diagnóstico e tratamento das doenças falciformes. Brasília: Ministério da Saúde; 2001. p. 9-11.

6. Barbosa AF, Soares C, Trujilo D, Fuser I, Cestari L, Contreras LR, et al., organizadores. Almanaque Abril, a enciclopédia da atualidade. São Paulo: Editora Abril; 2004.

7. Gonçalves MS, Bomfim GC, Maciel E, Cerqueira I, Lyra I, Zanette A, et al. BetaS-haplotypes in sickle cell anemia patients from Salvador, Bahia, Northeastern Brazil. Braz J Med Biol Res 2003; 36:1283-8.

8. Wainscoat JS, Bell JI, Thein SL, Higgs DR, Sarjeant GR, Peto TE, et al. Multiple origin of the sickle mutations: evidence from $\beta$ S-globin cluster polymorphisms. Mol Biol Med 1983; 1:191-7.
9. Curtin PD. The Atlantic slave trade: a census. Milwaukee: University of Wisconsin Press; 1969.

10. Gonçalves MS, Bomfim GC, Maciel E, Cerqueira I, Lyra I, Zanette A, et al. Beta S-haplotypes in sickle cell anemia patients from Salvador, Bahia, Northeastern Brazil. Braz J Med Biol Res 2003; 36:1283-8.

11. White FM, Berverly AF. Investigation of the hemoglobinophathies. In: Dacie JV, Lewis SM, editors. Pratical haematology. $6^{\text {th }}$ Ed. Edinburgh: Churchill Livingstone; 1984. p. 179-99.

12. Betke K, Marti HR; Schlicht I. Estimation of small percentage of foetal haemoglobin. Nature 1959; 184:1877-8.

13. Sutton M, Bouhassira EE, Nagel RL. Polymerase chain reaction amplification applied to the determination of $\beta$-like globin gene cluster haplotypes. Am J Hematol 1989; 32:66-9.

14. Sonati MF, Farah SB, Ramalho AS, Costa FF. High prevalence of deletional type of alpha-thalassemia among a black population of Brazil. Hemoglobin 1991; 15:309-11.

15. Figueiredo MS, Kerbauy J, Gonçalves MS, Arruda VR, Saad ST, Sonati MF, et al. Effect of alpha-thalassemia and beta-globin gene cluster haplotypes on the hematological and clinical features of sickle-cell anemia in Brazil. Am J Hematol 1996; 53:72-6.

Submitted on $27 /$ Sep/2004

Final version resubmitted on 14/Jan/2005

Approved on 27/Jan/2005 